\title{
Fathers, care and family policy in France: an unfinished revolution?
}

\section{Introduction}

In March 2013, the French socialist government announced a reform of the country's distinctive extended parental leave, following extensive and difficult negotiations with social partners and family advocacy groups. The new law, adopted in September 2013 and described by the government as one of its 'landmark' defining policy innovations, was presented as a means of encouraging more fathers to take advantage of post-birth leave from work, and thereby reducing France's excessive focus on motherhood ('hyper-maternalisation': see Castelain-Meunier, 2005) which is widely held to entrench traditional gender roles. However, the measure was criticised by many feminist and fathers' rights campaigners as both inadequate to address gender inequalities in childcare, and potentially worsening the situation of working-class mothers and their households.

The 2013 law on 'shared childcare' leave provides a timely opportunity to review the highly contested politics of fatherhood policies in France, a decade after the landmark extension of paternity leave by the 'plural left' government in 2002. We have earlier argued (Gregory and Milner, 2008) that France constitutes a distinctive fatherhood regime in the midst of a process of change. In this process of change, policy actors refer explicitly to other national models, notably the Swedish 'obligatory fatherhood' regime (see Duvander et al, 2010) and also to Germany's relative success in achieving reform and raising its position in gender equality indices in a very short time. However, France's own process of change displays a high degree of path dependency. Nevertheless, a combination of societal modernisation and political reflexivity has opened up a space for individual and collective agency (Gregory and Milner, 2012a).

The term 'fatherhood regime' denotes a bundle of rights and responsibilities defining fathers and fathering in law and seeking to shape the behaviour of individuals and households (Hobson and Martin, 2002). The nature of the rights and responsibilities will vary according to each specific regime, according to the intentions of legislators and other law-makers (such as judges) but these tend to cluster around rights of fathers after couple separation, family benefits and the tax-welfare nexus (including any expectations that fathers should contribute to children's upkeep after separation), explicit parenting support for fathers, and targeted measures to support working parents such as paternity leave. Work on fatherhood regimes posits that the institutional framework for fatherhood matters and that contemporary fathering practices are located within two triangles: that of the state, market and family; and that of the father, mother and child/ren, and moreover that there are contradictory elements in both (see Hobson, 2014).

This article focuses on the last element of the French fatherhood regime as listed above, that is, support for fathers at work, as this is the policy area which has driven change in recent years. In this France corresponds to a more general pattern of change in rich western countries away from the male breadwinner model towards the adult worker model in which both parents remain in the labour market (Ferragina and Seeleib-Kaiser, 2013; Gornick and Meyers, 2008; Lewis, 2006). Such a shift in labour market and caring behaviour is generally held to require supportive policies which provide assistance to parents whilst they withdraw temporarily from paid employment following childbirth or at other times during their children's development but also enable them not to lose the link with the labour market altogether, that is, a corresponding shift in family policies away from cash transfers and towards support for leave policies and childcare provision (Thévenon and 
Gauthier, 2011). Just as some policies - household rather than individual taxation, long maternity leave, and limited public childcare provision - are seen to encourage the choice of a male breadwinner, female carer (or female part-time carer) model (Cooke and Baxter, 2010), so too employment-focused family policies can support more gender-equal behaviour through individual tax regimes, leave policies and childcare provision (Brighouse and Wright, 2009). We have also argued (Gregory and Milner, 2008) that working time needs to be taken into account when discussing men's capability to balance work and family life (see also Gregory and Milner, 2012b; Hobson, 2014).

Although as noted a broad policy shift in this direction may be identified in rich western states, it takes on different forms and policy change has been uneven, in line with the idea of an 'incomplete' revolution in family roles and relationships (Esping-Andersen, 2009). Although women's employment patterns have come increasingly to resemble those of men, the corresponding shift in gendered division of responsibilities has followed a slower and more disrupted rhythm of change, prompting observers to highlight uneven and sometimes stubborn processes of 'lagged adaptation' (Gershuny et al, 1994). Changes in family policy take place on several levels, including cultural, ideational and attitudinal as well as material (Mätzke and Ostner, 2010), and there may be considerable time lags in the process whereby change at one level influences change in another (Pfau-Effinger, 2005, 2012). Institutions matter, too, and are likely to provide powerful explanations for variety in the pace and form of change as well as sticking-points which may emerge in processes of change. For example, a key component of leave policies which strongly determines uptake is replacement levels of statutory payments (Moss, 2013; Ray et al, 2010) but there is likely to be significant policy resistance to increases in replacement levels in liberal market economies or other forms of residual welfare state such as Mediterranean family-care-based regimes (Cooke and Baxter, 2010).

This article reviews the impact of the 2002 extension of paternity leave and the process of reforming France's long parental leave, with the aim of identifying the levers of change and sources of resistance to change. France provides a useful case study because of its traditionally distinctive family policy, based on conservative support for childbirth or natalism, with generous family benefits and explicit support for larger families. Its welfare system is characterised by a high degree of horizontal distribution, that is, support for households with children (see e.g. Levy, 2005). Family policy is highly institutionalised which gives public prominence to pro-natalist family advocacy groups. At the same time, a strong push for gender equality has emerged at key times to inflect the direction of family policy (Commaille, 2001). Particularly influential in this respect has been a more or less institutionalised nexus of academics, campaigners and feminist politicians which at certain times has created the conditions for a specific form of 'state feminism' (Mazur, 2007).

Support for working parents, or a policy of 'reconciliation of work and family life' aimed principally at mothers, explains at least in part a relatively high fertility rate. In 2011, at 2.01, the fertility rate exceeded the replacement rate of 2.0 for the fourth consecutive year, and although it dropped slightly in 2012 to 2.0 it remained relatively high in European comparison. Between 2008 and 2012 France had the second-highest fertility rate in the EU, behind Ireland (Moss, 2013; SPSS, 2013). However, the means of supporting working mothers focused largely on childcare provision (Fagnani, 2012; Fagnani and Math, 2011), with relatively little attention to gender equality in the domestic sphere. The persistent tension between conservative natalism and gender equality helps to explain 
both France's weak fatherhood regime and also the recent, but hesitant, shift towards stronger fathers' rights.

As will be explored further in this article, these tensions raise wider questions about what constitutes 'fatherhood policies' aimed at enabling fathers to achieve a better balance between work and family life, as surveys increasingly indicate that they wish to do (Gregory and Milner, 2012b). Redressing the imbalance between men's and women's patterns of paid employment and domestic care is central to any programme of gender equality, and yet relatively little attention has been paid in public discourse and policy outputs to men's work-life balance compared to that of women's. Locating men in the 'work-life nexus' cannot simply be a matter of applying the same policies as those thought or found to help women to negotiate paid employment and motherhood, but must take account of men's pre-existing behavioural orientations and must also tackle societal expectations of men's roles (McDonald and Jeanes, 2012) and implicit gender-coding of norms and policies, in order to increase their sense of entitlement to supportive measures (Hobson, 2014).

These wider questions are discussed further below with specific reference to the French case where a traditional 'hyper-maternalisation' of family policy may be expected to constitute a powerful constraint on the development of 'fatherhood policies' and the emergence of a strong fatherhood regime. This article focuses on paternity leave and fathers' share of parental leave, which form an important part of the employment-related component of fatherhood regimes. Comparative research indicates that paternity leave of at least two weeks' duration helps to increase father involvement and improve child development outcomes (Huerta et al, 2012). We also discuss in the concluding section the relationship between these employment-related rights and other aspects of France's fatherhood regime.

\section{Paternity leave and the (partial) creation of a new norm of 'involved fatherhood'}

The extension of paternity leave took place in 2002 as the centrepiece of a set of measures aimed at creating a new norm of 'involved fatherhood'. In addition to the three days' leave already available to fathers on the birth of a child, fathers now had the right to eleven days' leave (eighteen in the case of multiple births). In order to access the leave, fathers must notify their employer a month in advance and are entitled to a wage-related benefit funded by the health insurance scheme and administered by the family benefits agency. The extension of paternity leave placed France around half-way along the spectrum of EU member states in terms of generosity of provision, close to countries such as Denmark and Netherlands characterised by leave of around average duration but shorter than the pioneers such as Sweden and lower replacement levels (Moss, 2009).

The measure, hailed at the time as a significant breach in France's mother-centred family policy, was largely successful in 'normalising' fathers' presence at home during the first weeks of a child's life (or arrival in the home, in the case of adoption). From its introduction, take-up of the new paternity leave was relatively high, at around $59 \%$ in its first year of existence. It was estimated at around two thirds of eligible employees in 2005 (DREES, 2005) and the constant number of beneficiaries of statutory paternity pay indicates that is has remained around this level since then. Organisational case studies also found that paternity leave is almost taken for granted by male employees, 
particularly those working in larger firms (Gregory and Milner, 2011). Most fathers who take up leave also use the full eleven days (DREES, 2005).

However, the constant rate of take-up also indicates some difficulties for around a third of employees. Whilst paternity leave has become the norm for lower-paid employees, it is less widely used by higher grade employees. This may be because these higher-paid employees are able to access flexible working without having to face the income ceiling of statutory paternity pay, but is also thought to reflect the culture of presenteeism (on which, see Gatrell in this issue) which is widely discussed in management magazines and is thought to be affecting increasing numbers of managerial employees, of whom approximately 60\% are men (Pak and Zilberman, 2013; SPSS, 2013), although reliable data are scarce precisely because it is a 'hidden phenomenon' which does not appear in working time statistics.

Because take-up of paternity leave appeared to be limited by such constraints, a proposal was floated in 2011 to make paternity leave compulsory. The idea proved popular in public opinion: 78\% of those interviewed by pollsters Ifop professed themselves in favour of compulsory paternity leave ( $75 \%$ of men and $80 \%$ of women), with younger respondents more supportive (Ifop, 2011). The idea was launched by the president of the employers' peak association Medef, Laurence Parisot, in an interview with Elle magazine (Parisot, 2011). At the same time, and in the context of national social partner negotiations, the equality officer of one of the two largest trade union confederations, the CFDT (Confédération Française Démocratique du Travail), Monique Boutrand, argued that paternity leave should be extended to two months. However, most academics and gender equality campaigners argued that further extension of paternity leave was less of a priority than reform of parental leave.

The employers' association Medef has also sought to encourage 'best practice' policy dissemination on support for fathers at work. Working with the Observatory for Societal Responsibility of Businesses (ORSE), it sponsored a survey of employers' own views and practices on work-family reconciliation for fathers (ORSE, 2010). In 2012, Jérôme Ballarin, head of the Observatory for Equal Parenting at Work and a member of the state's High Commission on Gender Equality, was commissioned to report to government on ways for companies to promote work-life balance for fathers as well as mothers. Ballarin launched a voluntary code of conduct for businesses, based on a range of measures including employer top-ups for higher paid employees wishing to take up paternity leave: for example, at Axa, take-up of paternity leave had risen from $66 \%$ in 2009 to $76 \%$ in 2011 following the introduction of a full salary guarantee (Ballarin, 2012). Twelve fathers interviewed for the report, who had all made changes to their working time arrangements in order to spend more time with their family, all expressed support for extended paternity leave, as well as for other measures such as reduced working time and the ability to request part-time working, workplace support for part-time and flexible working options, and greater use of working from home. Ballarin's report, based on the views and reports from leading employers, stopped short on precise recommendations for policy-makers, preferring instead to highlight good business practice, but suggested that shorter, better-paid parental leave with a non-transferable portion of postchildbirth leave for fathers would improve fathers' sense of entitlement.

The question of whether to extend paternity leave and/or make it compulsory was still live at the time of the presidential election in 2012. The campaign group Laboratoire pour l'Égalité proposed a 
'pact for equality' to which the successful candidate, François Hollande, pledged his commitment, and which included four main recommendations. The third of these, on encouraging fathers to share fully in childcare, specified a commitment to extend paternity leave alongside increased public childcare provision by half a million places. However, to date, paternity leave has not been a priority for legislators, who have instead focused on reforming France's long and poorly paid parental leave. In October 2012, paternity leave entitlement was extended from biological fathers co-resident with mothers to include all co-resident partners of mothers, in line with a wider concern about the social policy implications of 'recomposed families' which now account for around $20 \%$ of all families in France.

\section{The tortuous process of reform of parental leave: moving from a male breadwinner to an adult carer model?}

Whereas the 2002 reforms may be seen as a high-point of 'state feminism' characterised by highly institutionalised gender equality campaigners ('femocrats') with access to leading (left-wing) women politicians, the policy environment after 2002 was more fragmented and less coherent in its approach to family policy (Mazur, 2007). On one hand, a new consensus on the need for familyfriendly policies had emerged, whilst the space for policy ideas had also opened out and feminist campaigners were able to continue to operate at many levels. On the other hand, within the relevant ministries a return to more traditional approaches to family policy was evident, whilst women politicians were increasingly sidelined in the 'hyper-presidentialised' political system. Under Nicolas Sarkozy's presidency, the family and social affairs portfolio was led by centre-right Nadine Morano, known for her opposition to same-sex marriage. Incoming president François Hollande kept his election promise of gender parity in his government, but admitted during the campaign that women would not occupy the most powerful ministries (see Murray, 2012). Nevertheless, the combination of two experienced women politicians, Christiane Taubira in the justice ministry and Marisol Touraine in social affairs, in 2012 marked the return to a programme of modernising reform in family law and policy, whilst the symbolic reinstatement of a ministry for women's affairs headed by Najat Vallaud-Belkacem also signalled a new emphasis on gender equality policies.

France's distinctive parental leave has long been the subject of criticism, so the impetus for reform was established some time ago. Cross-national comparative research shows that long parental leave arrangements tend to reinforce 'hyper-maternalisation' since mothers are more likely to withdraw from the labour market than fathers, whose relative income is on average higher (Brighouse and Wright, 2009; Ellingsvæter ,2010; Thévenon and Solaz, 2013). As a result, a trend has emerged in advanced economies towards policies based on a non-transferable portion of leave (Moss, 2013) which, following the Swedish example, is often referred to as the 'daddy quota' of parental leave. The European Union has explicitly endorsed this model, which formed the basis of the social partner agreement leading to the revised parental leave directive in 2010.

In the French case, a long parental leave (of one year, renewable twice) was introduced in 1986 for parents of children under the age of three, but available from the third child only (Parental Education Benefit, Allocation Parentale d'Éducation or APE). In 1994, it was extended to parents of two children where the youngest was under three year of age, and also broadened to include a switch from full-time to part-time work as well as full withdrawal from the labour market. In 2004, 
parental leave, now renamed CLCA (Complément de Libre Choix d'Activité, or Support for Choice in Activity) was made available to parents from the first child, but for a shorter time (six months, renewable once) (Ananian, 2010).

The shorter leave for parents of one child raised again the broader question of the length of parental leave which had been aired for some time because of its gendered impact (Fagnani and Math, 2011; Pailhé and Solaz, 2007). At least $98 \%$ of recipients of APE were women. Essentially, the long parental leave amounted to a male breadwinner model whereby women withdraw from the labour market after the birth of children, particularly after the second child. Family policy summits and reports to government (see e.g. Pécresse, 2007) floated proposals to reduce parental leave, make it available to all parents of young children regardless of the size of family, and make leave better paid. These ideas were taken up by incoming President Nicolas Sarkozy, who announced further reform of the CLCA in 2009, with the addition of a new, shorter and better paid leave (COLCA). However, take-up of the new leave was very low and by 2011 fathers' share of leave recipients had increased from $2 \%$ to only $4 \%$ (Grésy, 2011). Furthermore, feminist campaigners argued that shortening parental leave without measures to reduce childcare costs considerably would have a disproportionate negative effect on lower-paid women, who are the main beneficiaires of CLCA. Subsequent interventions aimed at increasing the number of subsidised childcare places have been too limited to keep pace with rising demand (Fagnani, 2012), let alone address the labour market disadvantage of mothers in low-paid occupations.

Campaigners therefore shifted their focus to the introduction of a 'daddy quota'. Despite an initially favourable response from the right-wing Sarkozy administration (Windebank, 2012), no reform emerged before the presidential election, which instead became dominated by economic aspects of austerity. However, in March 2013, as part of a wider package of measures on gender equality, minister Najat Vallaud-Belkacem announced a new bill to reserve half of the existing six-month parental leave for the second parent, on a 'use it or lose it basis', for those expecting a first child. Longer leave entitlement of up to two and a half years will still apply to mothers expecting a second or third child, whilst fathers will be entitled to six months. The bill was finally adopted in January 2014, six months later than anticipated, following a high degree of opposition from centre-right MPs who criticised state 'intrusion' into family life. The new law aims to increase men's take-up of postchildbirth parental leave to $25 \%$ of eligible fathers from the take-up rate of $3 \%$.

However, many campaign groups have been critical of the new law. Although it takes the idea of the 'daddy quota', by applying it to the existing long leave it does not address the labour market disadvantage of mothers in relation to men, or of lower-paid women. Instead, it is likely to result in only very marginal additional uptake by fathers, but rather a shortening of leave for mothers, in a context of employment scarcity. Human resources managers' associations as well as family advocacy groups pointed out that most families would lose out financially from a long period of withdrawal from the labour market. Fathers' rights groups SOS Papas welcomed the move but argued that the government showed inconsistency in claiming to promote father involvement whilst not addressing the issue of non-resident fathers' contact with children after separation. Mothers' campaign group SOS les Mamans meanwhile protested that rights for men meant the loss of rights for mothers (see e.g. Kovacs, 2014). These disagreements indicate that policy still has a long way to go to satisfy advocates of greater father involvement, but also, as we discuss further below, highlight the political tensions which characterise fatherhood policies. 


\section{Conclusion}

This brief review of the decade or so after the landmark extension of paternity leave in France has revealed divisions between different approaches to family policy and thereby raised questions about what constitutes effective family policy. Most political actors agree that the norm of involved fatherhood is a desirable policy goal, as it is shown to have a positive impact on child development and corresponds to shifts in public opinion towards more gender-egalitarian roles in both employment and family life. However, policy-makers and campaign groups are divided on how to achieve this broad goal and indeed their approaches may be mutually incompatible.

We have focused here on one aspect of gender regimes, that is, measures to support fathers at work and encourage a more balanced division of time between home and the workplace. Our review highlights three key questions about what type of policy works best to encourage take-up by fathers and help to embed a societal norm of involved fatherhood. The first question concerns the extent to which policies need to target men as fathers rather than assuming that gender-neutral measures will be equally beneficial to both mothers and fathers. In the French case, we have argued that the prevalent approach to date has concentrated on employment rights for parents which in practice were taken up overwhelmingly by mothers. The reason for this 'hyper-maternalism' are both cultural and material: the earnings gap between men and women, coupled with the gap between replacement rates and average earnings, mean that in practice parental leave is used disproportionately by low-income women. This in turn reinforces societal assumptions about the gendered nature of care.

Rights aimed specifically at men such as paternity leave and 'obligatory' fatherhood measures such as 'daddy quotas' therefore increase fathers' sense of entitlement and can have wider symbolic significance in helping to breach an excessively maternalistic policy tradition. In the French case, paternity leave of around two weeks has now become an accepted norm. Recent discussion about how to strengthen this entitlement indicates that there is scope to extend the length as long as replacement rates are increased. Paternity leave can therefore contribute to a long, slow process of change but forms only a part of it. Parental leave shared between two parents with sufficient flexibility to respond to individual household needs also forms part of a package of fatherhood policies, with the potential to encourage greater paternal involvement as the child grows up (Moss, 2013).

However, the French case raises a second question which has also emerged in other countries where proposals for splitting leave entitlements between the parents are made (see e.g. Brandth, 2012, on Norway), that is, how new entitlements for fathers can be negotiated without mothers feeling that they have lost rights correspondingly. This question reflects some division within feminist thought between gender-egalitarian and female-centred strategies. It may be that such tensions need to be worked through as part of the longer-term process of change. However, they could also jeopardise the process of change if attention is not also paid to addressing women's labour market disadvantage relative to men by action, for example by state investment in childcare, measures to 
protect low-paid employment, and training and other measures to enhance women's labour market opportunities.

The third question relates to the extent to which the societal norm of involved fatherhood is diffused by specific measures, and whether they need to form part of a wider package or coherent overarching strategy. In the British case, for example, it has been argued that fatherhood policy was significantly boosted under New Labour but also weakened by the inconsistency of an approach which emphasised fathers' obligations (in particular, their financial obligations) more strongly than their rights (Lewis, 2002). Similarly, in France, fathers' rights groups argue that an imbalance still exists between the discourse of 'shared parenting' (co-parentalité)and the proportion of childcare orders granted to mothers rather than fathers after couple separation. They express disappointment that the current government's emphasis on raising fathers' take-up of parental leave has not also led it (yet) to review shared parenting arrangements after separation: a working group reported in 2014 that such a review would be timely but failed to make specific recommendations.

These questions confirm the idea of an 'unfinished revolution' in French family policy whereby the traditional association between care and motherhood has been breached but not fundamentally changed. They suggest that the process has not halted but will continue incrementally and in small steps, in line with change to date. The tensions in family policy are themselves part of the process of change and have the potential to enlarge the space for men's agency, whether individually or collectively. Moreover, there are increasing signs of shifts in public attitudes. Surveys published at the end of 2013 indicated very high levels of support for shared parental leave arrangements (89\% according to Ifop, 2012).

As noted, shared residence arrangements constitute a minority of cases but the number is growing, and the arrangements are gaining a wider cultural acceptance. After couple separation, children lived mostly or solely with their mother in $73.5 \%$ of cases in 2010 , but this figure had decreased from $80 \%$ in 2003 . In almost ten per cent of cases, children live mainly or solely with their father, with the remaining fifteen per cent or so in shared care arrangements (Boisson and Wisnia-Weill, 2012). The proportion of French men saying that having children is necessary for their own fulfilment has grown and is now the same as for women (around 60\%) (Boisson and Wisnia-Weill, 2012). Genderegalitarian attitudes have become more commonplace (see e.g. Mainguené, 2011), undermining the traditionally gendered norms of female caring (see e.g. Crompton and Lyonette, 2006). Younger men consistently display more desire to spend time on childcare, supporting the idea of longer-term change which will intensify as each generation reaches prime working age.

The combined pressures from fathers for stronger rights and from feminist campaigners for a more equal sharing of work and family responsibilities are therefore likely to intensify and to highlight the growing contradiction between the policy norm of shared care and the limited policy outputs to date.

\section{References}

Ananian, S. (2010) 'L'activité des mères de jeunes enfants depuis la mise en place du complément de libre choix d'activité', Études et Résultats de la DREES, no.726, 1-8pp. 
Ballarin, J. (2012) Parentalité et égalité professionnelle hommes-femmes: comment impliquer les hommes? Report to the Secretary of State for the Family, Paris.

Boisson, M. and Wisnia-Weill, V. (2012) 'Désunion parentale', Note d'analyse du Centre d'Analyse Stratégique, 16pp.

Brandth, B. (2012) 'Emotional dimensions of fathering and work-family boundaries', in P. McDonald and E. Jeanes (eds) Men, wage work and family, London and New York: Routledge.

Brighouse, H. and Wright, E. O. (2009) 'Strong gender egalitarianism', in J. C. Gornick and M. K. Meyers (eds) Gender equality. Transforming family divisions of labor, London/New York: Verso.

Castelain-Meunier, C. (2005) Les métamorphoses du masculin. Paris: Presses Universitaires de France.

Commaille, J. (2001) 'Famille: entre émancipation et protection sociale', Sciences Humaines, 115 (4) : 30-55.

Cook, L. P. and Baxter, J. (2010) "'Families" in institutional context: comparing institutional effects across western societies', Journal of Marriage and Family, 72 (3): 516-536.

Crompton, R. and Lyonette, C. (2006) 'Work-life balance in Europe', Acta Sociologica, 49 (4): 379393.

DREES (Direction des Recherches, des Études et des Statistiques) (2005) 'Congé de paternité', Études et Résultats, no.44.

Duvander, A-Z., Lappegard, T. and Andersson, G. (2010) 'Family leave and fertility:

Fathers' and mothers' use of parental leave and continued childbearing in Norway and Sweden', Journal of European Social Policy, 20 (1): 45-57.

Ellingsvæter, A. L. (2010) 'Feminist policies and feminist conflicts: daddy's care or mother's milk?,' in J. Scott, R. Crompton and C. Lyonette (eds) Gender inequalities in the 21st century, Cheltenham: Edward Elgar.

Esping-Andersen, G. (2009) The Incomplete Revolution: Adapting to Women's New Roles, Cambridge: Polity Press.

Fagnani, J. (2012) 'Recent reforms in childcare and family policies in France and Germany: what was at stake?' Children and Youth Services Review, 34 (3): 509-516.

Ferragina, E. and Seeleib-Kaiser, M. (2013) 'Determinants of a silent (r)evolution: Understanding the expansion of family policy in rich OECD countries', unpublished paper for Council of European Studies conference, Amsterdam, 27 June (this paper is cited with the permission of the authors).

Fagnani, J. and Math, A. (2011) 'The predicament of childcare policy in France: what is at stake?' Journal of Contemporary European Studies, 19 (4): 517-541. 
Gershuny, J., Goodwin, M. and Jones, S. (1994) 'The domestic labour revolution', in M. Anderson, F. Bechhofer and J. Gershuny (eds) The social and political economy of the household, Oxford: Oxford University Press.

Gornick, J. and Meyers, M. (2008) 'Creating gender egalitarian societies: an agenda for reform', Politics \& Society, 36 (3): 313-49.

Gregory, A. and Milner, S. (2008) 'Fatherhood regimes in France and UK', Community, Work and Family, 11 (1): 61-85.

Gregory, A. and Milner, S. (2011) 'Fathers and work-life balance in France and the UK', International Journal of Social Policy, 31 (1-2): 31-54.

Gregory, A. and Milner, S. (2012a) 'What's new about fatherhood?' Men and Masculinities, 14 (5): 588-606.

Gregory, A. and Milner, S. (2012b) 'Men's work life choices: supporting fathers at work in France and Britain', in P. McDonald and E. Jeanes (eds), Men, Wage Work and Family, London, New York: Routledge.

Grésy, B. (2011) L'égal accès des femmes et des hommes aux responsabilités familiales et professionnelles, Rapport au Ministère de la Solidarité et de la Cohésion Sociale, Paris.

Hobson, B. (2014) 'Introduction: capabilities and agency for worklife balance', in B. Hobson (ed.) Worklife balance. The agency and capabilities gap, Oxford: Oxford University Press.

Hobson, B. et Martin, D. (2002) 'Introduction', in B. Hobson (ed.) Making men into fathers. Men, masculinities and the social politics of fatherhood, Cambridge : Cambridge University Press.

Ifop (2011) Les Français et le congé paternité, Paris: Ifop.

Kovacs, S. (2014) La réforme du congé parental n'enchante pas les associations, Le Figaro, 21 January. Lewis, J. (2002) 'The problem of men: policy and behaviour in Britain', in B. Hobson (ed.) Making men into fathers. Men, masculinities and the social politics of fatherhood, Cambridge: Cambridge University Press.

Lewis, J. (2006) Children, changing families and welfare states. Cheltenham: Edward Elgar.

Levy, J. D. (2005) 'Redeploying the state: liberalization and social policy in France', in W. Streeck and $\mathrm{K}$. Thelen (eds) Beyond continuity. Institutional change in advanced political economies, Oxford University Press.

Mainguené, A. (2011) 'Couple, famille, parentalité, travail des femmes', Insee Première, no.1339: 4pp.

Mätzke, M. and Ostner, I. (2010) 'Introduction: change and continuity in recent family policies', Journal of European Social Policy, 20 (5): 387-398. 
Mazur, A. G. (2007) 'Women's policy agencies, women's movements and a shifting political context: towards a gendered republic in France' In J. Outshoorn and J. Kantola (eds) Changing state feminism, Basingstoke: Palgrave.

McDonald, P. and Jeanes, E. (2012) 'Introduction: locating men in the work-life nexus', in P. McDonald and E. Jeanes (eds) Men, wage work and family, London and New York: Routledge.

Moss, P. (2009) (ed.) International Review of Leave Policies and Related Research, 2009, London: University of London Employment Relations Research Series 102.

Moss, P. (ed.) (2013) International review of leave policies and research, London: International Network on Leave Policies and Research.

Murray, R. (2012) 'In Hollande's new government, women have half the jobs, but less real power than under Sarkozy', London School of Economics blog (http://blogs.Ise.ac.uk/europpblog/2012/05/22/hollande-new-cabinet-women/).

ORSE (Observatoire de la Responsabilité Sociétale des Entreprises) (2010) Patrons papas: paroles de 10 dirigeants sur la conciliation travail et vie privée, Paris: ORSE.

ORSE (2013) Les hommes, sujets et acteurs de l'égalité professionnelle, Paris: ORSE.

Pailhé, A. and Solaz, A. (2007) 'Inflexions et trajectoires professionnelles des hommes et des femmes après la naissance d'enfants', Recherches et Prévisions, no.90: 5-16.

Pak, M. and Zilberman, S. (2013) 'La durée du travail des salariés à temps complet', DARES Analyses, no.047.

Parisot, L. (2011) Aujourd'hui, je suis plus féministe que jamais, Elle Magazine, 4 March (available online at ).

Pécresse, V. (2007) Mieux articuler vie familiale et vie professionnelle. Rapport présenté au Premier ministre, February.

Pfau-Effinger, B. (2005) 'Culture and welfare state policies', Journal of Social Policy, 34 (1), 3-20.

Pfau-Effinger, B. (2012) 'Women's employment in the institutional and cultural context', International Journal of Sociology and Social Policy, 32 (9/10): 530-543.

Ray, R., Gornick, J. C. and Schmitt, J. (2010) 'Who cares? Assessing generosity and gender equality in parental leave policy designs in 21 countries', Journal of European Social Policy, 20 (3): 196-216.

SPSS (Service Public de la Sécurité Sociale) (2013) Projet de loi des finances de la Sécurité Sociale. Partie I: Données de cadrage, Paris: SPSS.

Thévenon, O. and Gauthier, A. H. (2011) 'Family policies in developed countries: a "fertility booster" with side effects', Community, Work and Family, 14 (2): 197-216.

Thévenon, O. and Solaz, A. (2013) Parental leave and labour market outcomes: lessons from 40 years of policies in OECD countries, Paris: INED, Working Document 199. 
Windebank, J. (2012) 'Reconciling work and family life for French mothers in the Sarkozy era.

Working more to earn more?' International Journal of Sociology and Social Policy, 32 (9-10): 576588. 